\title{
PROSES SOSIALISASI DAN INTERNALISASI NILAI-NILAI KE-ISLAMAN PADA KELAS MENENGAH MUSLIM DI SURABAYA
}

\author{
Syukron Djazilan \\ Universitas Nahdlatul Ulama Surabaya \\ Syukrondjazilan@unusa.ac.id
}

\begin{abstract}
Abstrak: Tujuan penelitian ini adalah untuk mendeskripsikan proses sosialisasi dan internalisasi nilai-nilai Ke-Islaman pada kelas menegah muslim di Surabaya. Metode penelitian ini menggunakan kualitatif deskriptif. Penelitian ini dilakukan di di Kota Surabaya tepatnya adalah Masjid Al Akbar dan Masiid Al Falah. Teknik pengumpulan data berupa wawancara, dan pengamatan. Teknik analisis data menggunakan tiga tahap yaitu tahap orientasi data yang didapat dilapangan, tahap reduksi data dan tahap seleksi. Uji keabsahan data pada penelitian ini menggunakan uji kredebilitas, uji dependabilitas, uji konfirmabilitas. Hasil penelitian menunjukkan bahwa: (1)Proses terjadinya sosialisasi dan internalisasi nilai keislaman berlangsung panjang, dari bangku sekolah hingga dewasa. Pada usia dewasa mereka mendapatkan bimbingan melalui forum-forum dakwah oleh ustad/muballigh. Inilah yang disebut dengan belajar sepanjang hayat (life long education).(2) Proses internalisasi dan sosialisasi terkait pelibatan individu yang siap menerima dan mendukung guna menjadikan pendidikan informal semakin meningkatkan taraf kehidupan kelas menengah muslim Surabaya. Saran yang direkomendasikan pada penelitian ini adalah: Peran keluarga dalam membentuk manusia ideal berawal dari keluarga, oleh karenanya perlu usaha antar lembaga masyarakat yang mendukung agar pendidikan informal yang dijalankan di dalam keluarga bisa dan mampu berjalan dan mengahdirkan insan paripurna.
\end{abstract}

Kata Kunci : sosialisasi, internalisasi, nilai keislaman dan kelas menengah

\begin{abstract}
Abstrac: The purpose of this study was to describe the process of socialization and internalization of Islamic values in the Muslim middle class in Surabaya. This research method uses descriptive qualitative. This research was carried out in the city of Surabaya precisely mosque Al Akbar and mosque Al Falah. Source collection techniques in the form of interviews, and observations. Source analysis techniques use three stages, namely the orientation phase of the data obtained in the field, the source reduction stage and the selection stage. The validity of the source in this study uses credibility test, dependability test, confirmability test and dependability test. The results showed that: (1) The process of the occurrence of socialization and internalization of Islamic values lasted long, from school to adult. In adulthood they get guidance through da'wah forums by clerics / preachers. This is called life long education. (2) The process of internalization and socialization related to the involvement of individuals who are ready to accept and support in order to make informal education increasingly improve the standard of living of the Surabaya Muslim middle class. Suggestions recommended in this study are: The role of the family in forming an ideal human being starts from the family, therefore it needs an effort among community institutions that support so that informal education that is run in the family can and is able to walk and devote complete people.
\end{abstract}

Keywords: socialization, internalization, Islamic values and middle class 


\section{PENDAHULUAN}

Beberapa tahun ke depan, Indonesia diperkirakan memperoleh bonus demografi berupa besarnya populasi yang komposisinya didominasi kaum muda, relatif sejahtera, dan berdaya beli tinggi. Dalam diskursus sosiologis, mereka biasa disebut kelas menengah. Pada tahun 2020, diestimasikan kelas menengah di Indonesia menembus 140 juta orang. Perkiraan itu disampaikan Boston Consulting Group (BCG) Singapura dalam laporan yang berjudul Asia's Next Big Opportunity: Winning Over Indonesia's Middle Class and Affluent Consumers tahun $2012^{1}$.

Menurut BCG, pada tahun 2012 jumlah kelas menengah di Indonesia sekitar 74 juta orang. Namun dalam beberapa tahun ke depan, jumlahnya akan melesat hingga dua kali lipat. Asumsinya, setiap penduduk dengan penghasilan $\mathrm{Rp}$ 2 juta- Rp 7,5 juta per bulan masuk kualifikasi kelas menengah. Pemicunya, selain stabilitas ekonomi yang bisa mendorong pertumbuhan, juga postur demografis Indonesia di masa depan yang dikuasai kalangan usia produktif. Kalkulasinya didasarkan pada perhitungan statistik bahwa pada tahun 2012, sebanyak 62 persen penduduk Indonesia berada di usia produktif, antara 20-65 tahun. Sedangkan 27 persen lainnya berusia di bawah 15 tahun.

\footnotetext{
${ }^{1}$ Taufik, Rising Middle Class InIndonesia: Peluang Bagi Marketer dan Implikasi BagiPolicy Maker (Jakarta: Kompas Gramedia, 2012), 32.

2 Mohammad Afifuddin, "Kelas Menengah Terdesentralisasi”, Jawa Pos, (03 April 2014), 4. ${ }^{3}$ http://www.bcgsea.com. Diakses pada tanggal 24 Oktober 2016.

${ }^{4}$ Taufik, Rising Middle Class..., 40.

${ }^{5}$ Gerry Van Klinken dan Ward Berenschot (ed)., In Search of Middle Indonesia: Kelas Menengah
}

Persentase 27 persen itulah di kemudian hari yang akan tumbuh menjadi penopang kelas menengah Indonesia ${ }^{2}$.

Poin paling penting dari laporan BCG itu adalah munculnya potensi penyebaran kelas menangah di Indonesia. Pertumbuhan kelas menengah yang selama ini didominasi oleh kawasan Jakarta, Bogor, Tangerang, Depok, Bekasi (Jabodetabek) akan menyebar (terdesentralisasi) ke kota-kota lain. Selain kota-kota besar seperti Surabaya, Medan, Bandung, dan Makassar, kelas menengah di kota-kota lain juga diproyeksikan akan tumbuh pesat. BCG memperkirakan, jika saat ini baru ada 12 kota besar di Indonesia yang memiliki lebih dari 1 juta kelas menengah, maka pada tahun 2020 jumlahnya akan melonjak hingga 22 kota $^{3}$.

Desentralisasi kelas menengah sebagaimana diprediksi BCG di atas tentu akan membawa dampak terhadap kotakota yang mengalami perubahan postur demografi terkait dengan penyebaran kelas menengah tersebut. Sebagaimana hasil riset Taufik ${ }^{4}$ di sepuluh kota besar di Indonesia maupun hasil riset Klinken, $\mathrm{dkk}^{5}$ di kota-kota menengah di Indonesia yang menunjukkan bahwa perilaku kelas menengah di kota-kota di luar Jakarta tidak hanya terkait dengan sikap politik sebagaimana pernah dibahas Tanter dan Young $^{6}$ dan Bahruddin ${ }^{7}$ atau tindakan

\footnotetext{
di Kota-Kota Menengah (Jakarta: Yayasan Pustaka Obor Indonesia, 2016), 73.

${ }^{6}$ Richard Tanter dan Kenneth Young, Politik Kelas Menengah Indonesia (Jakarta: LP3ES, 1993), 56.

7 Muh. Bahruddin, "Mitos Kelas Menengah ke Atas dalam Desain Iklan Politik Risma Bambang”, Nirmana, Vol. 14, No. 1 (2012), 1.
} 
Syukron Djazilan - Proses Sosialisasi dan Internalisasi Nilai-Nilai Ke-Islaman pada Kelas Menengah Muslim di Surabaya

konsumtif dari kelas menengah sebagaimana dikaji Taufik, Pambudy, Jati, dan Arizal dalam Raharjo. ${ }^{8}$ Perilakuperilaku khas kelas menengah di kotakota besar di Indonesia juga terkait dengan preferensi kultural, keagamaan dan juga pendidikan Rahardjo ${ }^{9}$; $\operatorname{Hasan}^{10}$.

Kelas menengah sebagai sebuah kategori diferentiatif dan stratifikatif yang memiliki distingsi sosial terhadap kategori kelas sosial lainnya ternyata bukan entitas sosial yang tunggal. Di dalam diri kategori kelas menengah tersebut banyak difersifikasi yang merujuk pada kecenderungan perilaku tertentu. Hady dan Gani dalam risetnya mengemukakan ada delapan segmen bagi kelas menengah, yakni expert, climber, aspirator, performer, trendsetter, follower, settler dan flower $^{11}$. Secara umum golongan kelas menengah dicirikan dengan lapis sosial tertentu yang memiliki ciri hidup nyaman, hidup seperti kalangan atas, lebih meningkatkan karir di korporasi, gampang berteman dengan siapa saja sehingga memiliki banyak komunitas sosial. Akan tetapi secara khusus, beberapa perilaku kelas menengah bersifat segmented sebagaimana diuraikan oleh Hady dan Gani di atas.

\footnotetext{
8 Wasisto Raharjo Jati, "Less Cash Society: Menakar Mode Konsumerisme Baru Kelas Menengah Indonesia", Sosioteknologi, Vol. 14, No.2 (2015), 2 .

9 M. Dawam Rahardjo, Masyarakat Madani: Agama, Kelas Menengah dan Perubahan Sosial (Jakarta: LP3ES dan LSAF, 1999), 268.

10 Noorhaidi Hasan, Islam di Kota-Kota Menengah Indonesia: Kelas Menengah Gaya Hidup, dan Demokrasi (Jakarta: Yayasan Pustaka Obor Indonesia, 2016), 21.
}

Richardson, dkk dalam buku Principles and Practice of Informal Educationmenguraikan bahwa kelas menengah memiliki hubungan kerja, komunitas kerja, komunitas sosial, maupun komunitas dalam pendidikan dewasa yang memiliki koneksi satu dengan yang lain. ${ }^{12} \mathrm{Hal}$ tersebut kompatibel dengan apa yang dikemukakan Akram Fouad Khater bahwa kelas menengah yang menempati ruang sosial tertentu, seperti halnya komunitas sosial dalam sebuah komunitas urban yang tinggal di kota, cenderung memiliki hubungan kuat satu dengan yang lain. ${ }^{13}$

Di antara banyak analisis dan klasifikasi mengenai perilaku dan kecenderungan kelas menengah di berbagai wilayah perkotaan Indonesia, salah satu kajian yang menarik adalah mengenai preferensi sosial kelas menengah di sektor pendidikan. Pendidikan, dalam berbagai literatur disebutkan terbagi dalam berbagai klasifikasi, yakni pendidikan formal, pendidikan non-formal, dan pendidikan informal. Merujuk pada Pasal 1 Ayat 13 Undang-Undang Nomor 20 Tahun 2003 tentang sistem pendidikan nasional tertulis bahwa jalur pendidikan ada tiga,

\footnotetext{
${ }^{11}$ Yuswo Hady dan Kemal E Gani, 8 Wajah Kelas Menengah (Jakarta: Gramedia Pustaka Utama,2015), xii.

${ }^{12}$ Linda Deer Richardson, dkk., Principles and Practice of Informal Education: Learning Mary Wolfe (London and New York: Routledge Falmer, 2001), xi.

${ }^{13}$ Akram Fouad Khater,Inventing Home: Emigration, Gender and The Middle Class In Libanon 1870-1720 Epiloge: The Making of a Middle Class (London: University California Press, 2001), 179.
} 
yaitu pendidikan formal, pendidikan nonformal dan pendidikan informal ${ }^{14}$.

Terkait preferensi kelas menengah dalam memilih institusi pendidikan formal, Taufik memaparkan hasil riset yang dilakukan MarkPlus Incorporation di sepuluh kota besar di Indonesia, yakni Bandung, Banjarmasin, Denpasar, Medan, Manado, Makassar, Palembang, Pekanbaru, Semarang, dan Surabaya. Hasil survei MarkPlus Incorporation tersebut menunjukkan bahwa kebutuhan belanja pendidikan formal kelas menengah di berbagai kota tersebut setara dan sama pentingnya dengan belanja kebutuhan kesehatan, belanja di klinik kecantikan untuk perempuan dan mengkonsumsi produk perawatan tubuh bagi pria, belanja di pusat perbelanjaan modern (mall), makan dan minum di kedai makanan maupun minuman franchise yang tersebar di cafe-cafe berkelas, maupun aktualisasi hobi dengan komunitas sosialnya.

Kebutuhan pendidikan informal bagi masyarakat kelas menengah juga didasari oleh motif individual, di mana masingmasing individu diasumsikan memiliki hasrat tinggi terhadap ilmu agama dan ilmu pengetahuan yang diproleh melalui jalur pendidikan informal di dalam keluarga yang berlangsung dari masa

14 Dokumen File pdf tentang Undang-Undang Republik Indonesia Nomor 20 Tahun 2003 Tentang Sistem Pendidikan Nasional, 2.

15 Yukiko Inoue (Ed), Online education for Lifelong Learning (London: Information Science Publishing, 2007), 122, ini berangkat dari pengertian konsep Cropley Long Life Education yang menyebutkan bahwa manusia memiliki kewajiban belajar sepanjang hayat 1) sadar bahwa dirinya harus belajar sepanjang hayat, 2). Memiliki pandangan bahwa belajar hal yang baru merupakan cara logis untuk mengatasi masalah, 3). Bersemangat tinggi untuk belajar pada semua kanak-kanak hingga dewasa ${ }^{15}$.Termasuk ketika kelas menengah muslim tersebut mengikuti kegiatan keagamaan yang ada di lingkungan sekitar. Seperti kegiatan dakwah atau pengajian, pendidikan TPQ/TPA, majelis taklim dan pusat belajar agama yang berkembang di lingkungan masyarakat masing-masing.

Terkait hal tersebut, salah satu bentuk pendidikan informal yang dipilih kelas menengah adalah mengikuti kajian/pengajian agama di Masjid/Musholla atau yang akrab dikenal sebagai majlis taklim. Bentuk dan ragam majlis taklim di Surabaya sangatlah beragam. Salah satu contoh, jamaah pengajian "Murobhatotul Ittihadiyah" pendirinya Al-Maghfurlah KH. Abdul Wahid Hudzaifah QS, yang kemudian dilanjutkan oleh putranya, KH. Syafi'uddin Abd. Wahid. QS. (Pengasuh PP. Darul Ulum Al-Wahidiyah Gersempal $)^{16}$. Begitu juga kegiatan Jama'ah Al-Khidmah (Majlis Dzikir \& Maulidurrasul SAW) yang di dalamnya juga diisi dengan acara majlis taklim yang didirikan oleh KH. Achmad Asrori bin Utsman al-Ishaqi, pengasuh pondok pesantren Al-Fihrah Kedinding Surabaya. Beliau dan ayahnya juga merupakan mursyid tarekat Qodiriyah Naqsyabandiyah ${ }^{17}$.

level, 4) menyambut baik perubahan (open minded), 5) percaya bahwa tantangan sepanjang hidup adalah peluang untuk belajar.

${ }^{16} \mathrm{http} / / / \mathrm{www}$.naqsyabandiyah-gersempal.org dikases 24 Oktober 2016. Kegiatan jamaah tarikat naqsyabandiyah Gersempal ini dilaksanakan setiap bulannya sesuai jadwal, isi acara berupa kegiatan pengajian, dilanjutkan dengan ceramah agama.

${ }^{17}$ http://alkhidmahrobayan..co.id dikases 24 Oktober 2016. Kegiatan ini menyebar hingga seluruh propinsi di Indonesia, hingga mancanagera sampai Singapura dan Filipina. 
Syukron Djazilan - Proses Sosialisasi dan Internalisasi Nilai-Nilai Ke-Islaman pada Kelas Menengah Muslim di Surabaya

Beberapa tempat juga menyelenggarakan pendidikan informal bagi masyarakat luas seperti Masjid Nasional Al Akbar Surabaya, yang pelaksanaannya setiap hari dengan berbagai variasi kajian; mulai dari kajian fikih Islam dengan narasumber Prof. Dr. KH. Faisol Haq, M.Ag, hingga ilmu kesehatan yang diasuh oleh Dr. $\mathrm{H}$. Ahmad Sungkar, Sp.Kj$(\mathrm{TEAM}){ }^{18}$.Dengan demikian, masjidmasjid besar seperti Masjid Al-Akbar Surabaya yang lokasinya juga berada di pemukiman urban metropolitan menjadi lokasi strategis untuk menemukan aktivitas kelas menengah muslim dalam mengakses pendidikan informal.

Bertolak dari penjelasan dan deskripsi di atas, maka rumusan masalah pada penelitian ini adalah "Bagaimana proses sosialisasi dan internalisasi nilainilai ke-Islaman pada kelas menengah muslim di Surabaya?"

\section{METODE PENELITIAN}

Penelitian ini menggunakan jenis penelitian deskriptif-kualitatif dengan maksud mendeskripsikan secara sistematis, faktual dan akurat mengenai fakta-fakta dan sifat-sifat suatu fenomena yang terjadi. Penelitian ini dilakukan di Kota Surabaya tepatnya adalah Masjid Al Akbar dan Masiid Al Falah.

Peneliti melakukan analisis dan menafsirkan suatu fakta, gejala atau peristiwa yang terjadi pada objek yang diteliti yaitu kelas menengah muslim Surabaya, dalam konteks ruang dan waktu serta situasi lingkungan yang

${ }^{18}$ http://www.masjidalakbar.com/linkmenu.php?n amafile=kajianrutin diakses 24 Oktober 2016. terjadi secara alami, melalui interpretasi dari pengamatan yang dilakukan.

Adapun pengumpulan datanya yaitu dengan hasil wawancara, pengamatan, hasil pemotretan (manakala dibutuhkan), analisis dokumen kepustakaan terkait kajian kelas menengah muslim Surabaya, catatan lapangan yang telah disediakan peneliti saat dilapangan, yang telah terlampir, hal ini sebagai penguat data sebagai informasi atau sumber terhadap penelitian ini. Proses mencari hubungan, membanding, menemukan pola atas data yang didapatkan untuk dipaparkan dalam bentuk naratif-deskriptif, guna menjawab rumusan masalah yang diajukan dalam penelitian.

Dalam mengumpulkan data, analisis data dalam penelitian kualitatif memiliki beberapa tahapan diantaranya ${ }^{19}$ :

a. Tahap deskripsi atau tahap orientasi data yang didapat di lapangan. Tahap ini peneliti mendeskripsikan segala yang dilihat, didengar, dirasakan, maupun yang dicatat dalam wujud visual maupun audio visual terkait dengan informan di lapangan tentang kelas menengah muslim Surabaya.

b. Tahap reduksi atau pemilahan terkait data yang didapat dalam wawancara, observasi, tanya jawab yang dilakukan terhadap informan (kelas menengah). Dalam hal ini pertanyaan telah dipersiapkan oleh peneliti.

c. Tahap seleksi, pada tahapan ini peneliti menguraikan, mengidentifikasi, menganalisis segala informasi yang didapat dari sumber atau informan dilakukan guna

19 Sugiyono, Metode Penelitian Pendidikan; Pendekatan Kuantitatif, Kualitatif dan $R \& D$. (Bandung: Alfabeta. 2007), 80. 
ditetapkan mana saja data yang relevan terkait penelitian kelas menengah muslim Surabaya.

Pada bagian pengecekan keabsahan ini bertujuan memastikan bahwa data yang didapatkan sesuai dengan yang diharapkan dari sumber yang diteliti serta informasi yang didapatkan sesuai rencana dan relevan sebagai sumber data di lapangan, guna memperkuat hasil penelitian. Uji keabsahan data pada penelitian kualitatif meliputi uji credibility (validitas internal), transferability (validitas eksternal), dependability (reabilitas) dan confirmability (objektifitas).

\section{KAJIAN TEORI}

Dalam mempelajari interaksi sosial khususnya internalisasi nilai keislaman terhadap masyarakat kalangan menengah di Surabaya ini biasa menggunakan pendekatan tertentu, yang dikenal dengan nama interaksionist prespektive. Di antara berbagai pendekatan yang digunakan untuk mempelajari interaksi sosial, dijumpai pendekatan yang dikenal dengan nama kontruksi sosial yang bersumber dari pemikiran Peter L. Berger dan Thomas Luckman.

Teori konstruksi sosial menyatakan bahwa setiap fakta yang hadir di tengahtengah masyarakat (realitas sosial)

\footnotetext{
${ }^{20}$ Peter L Berger dan Thomas Luckman, Tafsir Sosial Atas Kenyataan: Risalah Tentang Sosiologi Pengetahuan, (Jakarta: LP3ES, 1990), 23.

${ }^{21}$ Peter L. Berger, Langit Suci, Agama Sebagai Realita Sosial, (Jakarta:LPES,1994), 4-5.

22 Secara khusus pendidikan dilakukan oleh pelaksana pendidikan yaitu pendidik (guru, pamong belajar, tutor, pelatih, instruktur,
}

merupakan hasil proses dialektika. Peter L. Berger dan Thomas Luckman menyatakan terdapat dialektika antara individu menciptakan masyarakat dan masyarakat menciptakan individu. Kedua unsur ini saling berkaitan dan tidak dapat dipisahkan satu dengan yang lainnya. ${ }^{20}$

Proses dialektika tersebut setidaknya melalui tiga tahap yang oleh kedua tokoh itu disebut sebagai momen atau peristiwa. Pertama, eksternalisasi, yaitu usaha pencurahan atau ekspresi diri manusia ke dalam dunia, baik dalam kegiatan mental maupun fisik. Kedua, objektivasi, yaitu disandangnya produk-produk aktivitas tersebut baik bentuk fisik maupun mental. Ketiga, internalisasi. Proses internalisasi lebih merupakan penyerapan kembali dunia objektif ke dalam kesadaran sedemikian rupa sehingga subjektif individu dipengaruhi oleh struktur dunia sosial. $^{21}$

\section{TEMUAN PENELITIAN}

Murdiono (46) menggambarkan bahwa pengetahuan keilmuaan telah diperolehnya sejak taman Kanak-Kanak. Dia masih ingat bahwa Rukun Islam merupakan pokok bahasan yang diberikan pada saat itu. Tidak banyak yang diingat oleh Murdiono tentang nilai Islam yang diperolehnya dari bangku pendidikan formal. Menurutnya kewajiban untuk menghafal tanpa diikuti dengan praktik membuatnya mudah melupakan materi yang diajarkan di sekolah $^{22}$. Apalagi tanpa

wiydiaswara) terhadap peserta didik supaya lebih mampu berperan dalam melaksanakan tugas, pekerjaan dan kehidupannya dimasa depan. dibaca: Soedijarto, dkk, Ilmu \& Aplikasi Pendidikan: Bagian 4 Pendidikan Lintas Bidang (Bandung: PT. Imperial Bakti Utama,2007), 464. 
Syukron Djazilan - Proses Sosialisasi dan Internalisasi Nilai-Nilai Ke-Islaman pada Kelas Menengah Muslim di Surabaya

dibarengi dengan pembiasan praktek pengucapan rukun islam yaitu dua kalimat syahadat yang tidak hanya di ucapkan dengan lisan tetapi pengakuan dalam hati yang di implementasikan dengan tindakan, dengan menunaikan sholat lima waktu dalam sehari semalam ia lakukan sejak kecil dengan bimbingan orang tuanya.

Mengeluarkan zakat saat bulan suci ramadhan satu tahun sekali merupakan praktik langsung, berpuasa pada bulan ramadhan dengan latihan bersama bimbingan orang tua, ia dibelajarkan untuk tahu bagaimana pentingnya menahan lapar dan dahaga bagi orang haus, lapar yang menimpa orang tidak mampu serta pembelajaran terhadapat melaksanakan haji bagi mereka yang mampu menunaikan, inilah hasil didikan orang tua, guru Murdiono (46) selalu mengumandangkan di telinga saat pembelajaran di lembaga TPQ/MI begitu pula ketika di rumah. Sebagaimana ingatan nyanyian Murdiono (46) saat di wawancarai peneliti yang bisa dinarasikan disaat kecil mengaji di lembaga TPQ/MI seperti "rukun islam yang lima, syahadat, sholat, zakat, puasa pada ramadhan, haji bagi yang mampu". Siapa belum sholat dor...dor...dor... siapa belum zakat, nanti di akhirat Allah pasti melaknat. Bahkan dia ucapkan dengan berulang-ulang atas perintah panduan guru yang diikuti oleh Murdiono (46) serta temantemannya, kendatipun di saat masuk pendidikan SMP/MTs hal serupa tidak terulang, karena tingkat pendidikan dalam pembelajarannya berbeda lebih tinggi lagi tidak harus menghafal maupun mempraktikkan nyanyian dengan bahasa arab seperti dibawah ini yang ia ucapkan:

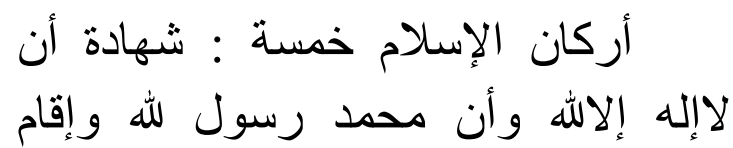

${ }^{23}$ Melatih anak perlu adanya pembiasaan yang dilakukan orang tua untuk mengarahkan segala

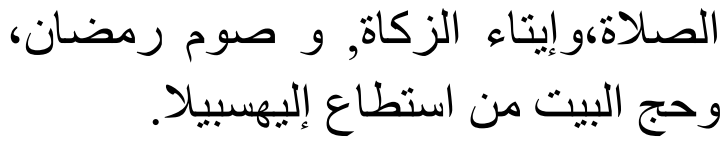

Demikian juga pengenalan terhadap rukun iman yang enam juga ia ingat lewat nyanyian sebagaimana berikut: "Rukun iman yang enam, beriman pada Allah, beriman pada malaikat-malaikat Allah, beriman pada kitab-kitab Allah, beriman pada rasul Allah, beriman pada hari akhir dan beriman pada khodo' kodhar Allah". Dilanjutkan juga dengan bahasa arab sebagai berikut dengan panduan guru dulu yang nyanyikan:

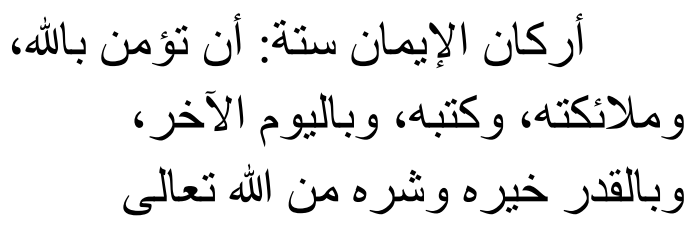

Nyanyian seperti inilah yang didengungkan Murdiono (46) saat sekolah di TPQ/MI, pembiasaan pada Murdiono (46) inilah menjadikan ingatan seumur hidup, tidak hanya itu saja praktek keagamaan yang dijalankan setiap hari saat di rumah melalui ibadah sholat lima waktu dhuhur, ashar, magrib, isya' dan subuh menjadi rutinitas kesehariannya, ditambah lagi saat bulan suci ramadhan dengan adaya pondok ramadhan yang diselenggarakan pihak sekolah menambah rutinitas kegiatan agama semakin banyak yang dilaksanakan beberapa minggu menjadikan Murdiono (46) semakin mantap dan praktek yang dilakukannya serta ketika mengaji di lembaga TPA/TPQ, tidak kalah penting sejak masih di bangku sekolah dasar orang tua Murdiono (46) memperhatikan betul apa saja yang dikerjakan, ketika saat bermain, sehabis sekolah bahkan ketika setelah selesai mengaji ${ }^{23}$.

langka demi masa depan anak. Baca: Gunawan Ardianto. A To Z Cara Mendidik Anak Aturan dan 
Proses sosialisasi nilai keislaman oleh ulama/kyai, ustad/ustdza, da'i dan mubaligh kepada masyarakat kelas menengah muslim Surabaya merupakan bagian integrasi yang dibangun antara jama'ah pendakwah melalui pesan perintah maupun larangan yang berlandaskan perintah Allah SWT dan rasulnya. Proses sosialisasi sangat penting bagi masyarakat muslim Surabaya guna menambah wawasan dan pengetahuan terhadap agama Islam.

Masjid, musholah (langgar), dan tempat ibadah orang Islam sebagai bagian rutinitas dan aktivitas menjalankan perintah agama setiap hari dalam menjalankan ibadah sholat lima waktu dhuhur, ashar, magrib, isya' dan subuh, dan dilanjutkan dengan khultum saat pagi sehabis sholat sunnah dhuha, tempat kegiatan agama bagi orang NU ialah adanya Jama'ah istighotsahan, tahlilan, yasinan, maniqiban, diba'an dan seni hadrah dan dakwah-dakwah pengajian agama yang dipandu oleh seorang kyai/tokoh sesepuh panutan keagamaan masyarakat sekitar.

Kegiatan tersebut sangat positif dalam membangun nilai-nilai keislaman sebagai wujud sosialisasi penyampaian pesan-pesan nilai keislaman bagi penyebarannya seperti halnya sejarah walisango hadir di nusantara dan perjuangan penyebarannya. Aktifitas semacam itu hingga hari ini masih terasa kental dalam mewarnai unsur kebudayaan mempraktikkan atribut keagamaan dan simbol bagi agama sebagai kesatuan yang tak terpisahkan, sehingga mampu diterima dimasyarakat. Kegiatan pengajian/ta'lim agama sangat membantu masyarakat kelas menengah dalam mendalami nilai-nilai keislaman pada prakteknya, peneliti ketahui dan pahami bahwa mereka membaur langsung dengan jamaah yang lain asalnya belum kenal dan ketemu akhirnya kenal satu sama lain sehingga membentuk sebuah komunitas/kumpulan, hingga adanya kegiatan pengajian/majelis taklim menjadi sarana pengukuh ukhuwa islamiyah bagi umat islam.

Kegiatan rutin agama bagi sebagian masyarakat kelas menengah muslim Surabaya menjadi bagian mereka untuk mengekpresikan diri dalam menyakini paham agama. Seperti yang dilakukan anggota jama'ah bapak Budiono, Murdiono dan Sholikin masyarakat asli kota Surabaya mengikuti pengajian rutin yang di adakan di masjid Al-Akbar Surabaya tiap minggu malam senin dan minggu pagi, berbagai tema menarik yang dikaji dan diulas dalam kaitan masalah sosial keagamaan.

Para jama'ah yang hadir tidak hanya dari kalangan akademisi, politisi bahkan pemerintahan disana hadir dari kalangan atas para pengusaha, pembisnis, pedagang, dari kalangan menengah, para pegawai, dokter, insinur, TNI, Polri, dan dari kalangan bawah ada petani, nelayan dan masyarakat biasa yang hidup di kota dan masyarakat sekitar yang menyempatkan waktunya untuk ikut hadir.

Para ustad/dai yang memberikan ceramah memahami bahwa kalangan yang hadir bermacam-macam sehingga apa yang disampaikan bisa diterima, dan diamalkan dalam kehidupan sehar-hari, pesan seperti selalu terucap saat acara majelis taklim mau diakhiri, bagi masyarakat Surabaya hal ini penting dalam menambah nilai-nilai keislaman guna menambah wawasan keilmuan mereka di bidang agama. Kadang proses seperti ini tidak dipahami yang merupakan bagian dari sosialisasi nilai-nilai keislaman dalam prakteknya di kehidupan nyata. Pemahaman tersebut tidak hanya berhenti di situ, mereka ada yang mengikuti pelatihan mengaji Alquran dan tafsirnya bagi yang tingkatan tinggi, ada yang juga ikut 
Syukron Djazilan - Proses Sosialisasi dan Internalisasi Nilai-Nilai Ke-Islaman pada Kelas Menengah Muslim di Surabaya

tilawatil qur'an dan metode-metode mengaji Al-qur'an bagi pemula dan pengajian kitab kuning serta cara berdakwah. Mereka memiliki keyakinan bahwa apa yang dilaksanakan dan dilakukan sangat memberi manfaat bagi mereka khusus di dunia dan akhirat. Bahkan diantara jamaah ada yang rela mendonaturkan sebagian rezekinya untuk kegiatan keagamaan guna mendukung kelancaran dan kepentingan kegiatan agama yang memberikan kepuasan sendiri bagi mereka.

Hasil temuan terhadap masyarakat muslim Surabaya, bahwa mereka sebagaian banyak mengaplikasikan dan mempraktikkan nilai-nilai keislaman melalui tindakan berupa perilaku hidup bersih, disiplin ibadah, positif berpikir dengan menunjukan sikap toleran baik pada orang lain, maupun penganut agama lain, religius, jujur, kerja keras, kreatif dengan berjualan saat ada acara bazar maupun kegiatan, mandiri tidak mudah bergantung pada orang lain, demokratis dalam berpikir, bersikap, betindak menilai sama hak dan kewajiban dirinya dan orang lain, rasa ingin tahu dibuktikan dengan selalu mengikuti kegiatan dakwah, majelis dan pengajian bagi masyarakat kelas menengah muslim Surabaya, semangat kebangsaan, cinta tanah air, menghargai prestasi diri, bersahabat komunikatif, cinta damai, gemar membaca dan peduli lingkungan, peduli sosial tanggung jawab. Itulah sikap, sifat yang dimiliki yang bisa peneliti amati untuk disimpulkan ${ }^{24}$.

Sebagai gambaran proses internalisasi, maka ditemukan dengan jelas bahwa terjadinya sosialisasi nilai-nilai keislaman yaitu melalui kegiatan adanya pengajian yang disampaikan oleh pak ustad kepada para jama'ah agar menjalankan nilai-nilai ajaran agama Islam seperti iman, Islam, ihsan,

\footnotetext{
${ }^{24}$ Obserasi, pada tanggal 2 Nopember 2014.

${ }^{25}$ Ibid.

${ }^{26}$ Kuntowijoyo. Muslim Tanpa Masjid: Esai-Esai Agama, Budaya, dan Politik Dalam Bingkai
}

sabar, jujur dapat dipecaya dengan menjalankan segala perintahnya dan menjauhi segala larangan. ${ }^{25}$

Murdiono (46), salah satu masyarakat Surabaya mendapatkan kesempatan untuk di wawancarai peneliti mulai awal penelitian, dengan gaya tampilan agamis, memakai kopyah atau peci dilepas dangan celana dasar warna krem ia bersama keluarga menyempatkan diri berdiam sesaat selesai sholat isya' dan dilanjutkan dengan sholat sunnah, sesudah itu keluar ke serambi masjid duduk-duduk bersama istri, keluarga di masjid al-Akbar Surabaya. Sehabis menunaikan kewajiban, sambil menikmati hidangan yang telah dipersiapkan dari rumah terlebih dahulu untuk bekal makan sehabis sholat, kemudian membuka dan menyiapkan makanan yang di bawah sebagai bekal makan bersama keluarga saat berada di masjid.

Analisis bahasan masjid yang dapat diberikan peneliti, bahwa masjid tidak hanya sebagai tempat ibadah khusus untuk menjalani sholat maupun kegiatan keagamaan saja, akan tetapi tempat merepresentasikan hubngan antara tuhan dengan manusia, hubungan manusia dengan manusia $^{26}$ yang merupakan ruang dakwah serta sarana aktivitas muslim di dalam mengaktualisasikan diri untuk dekat dengan wilayah-wilayah keagamaan.

Pemeroleh pengetahuan agama tentang nilai-nilai keislaman yang telah didapat, mereka aplikasikan dalam kehidupan seharihari, umpamanya saat ada tetangga mempunyai hajatan, maka para jamaah, maupun tetangga sekitar saling membantu dan ikut bergotong royong menyiapkan segala keperluan yang dibutuhkan baik secara materi maupun tenaga, juga pikiran inilah bentuk internalisasi nilai-nilai keislaman yang diimplementasikan dalam kehidupan

Strukturalisme Transendental (Bandung: Mizan. 2001), 1-8. 
real, contoh lain ialah menjaga kebersihan, banyak dari para jamaah kelas menengah muslim Surabaya yang mempraktikkan apa yang ia dapat saat mengikuti majelis taklim/dakwah keagamaan antara lain menjaga kebersihan dalam rumah utamanya toilet, maupun dapur yang terlihat bersih sebagaima peneliti ketahui dan membuang sampah pada tempatnya, serta gotong royong setiap minggu membersikan lingkungan sekitar bersama warga.

Pengetahuan agama islam yang di dapat tidak semata-semata dikarenakan hasil dari pendidikan sekolah, maupun masyarakat, akan tetapi hasil pembiasan diri anggota keluarga. Melalui peran ibu dan bapak yang mengajarkan anaknya, begitupun orang tua yang selalu mawas diri tidak hanya menuntut balik. Pembiasaan diri mandiri ini memunculkan sikap, tanggung Jawab pada aplikasi perilaku pencerminan akhlak mulia, menghormati orang tua baik secara perbuatan maupun lisan, tata krama, sopan santun dan bentuk kasih dan sayang yang selalu terlihat dalam kebersamaan keluarga bercengkerama dan senyum ceria. Inilah hasil pendidikan informal yang mampu digali peneliti dari kalangan masyarakat kelas menengah muslim Surabaya.

\section{PEMBAHASAN PENELITIAN}

Berdasarkan temuan, dimana para kelas menengah muslim Kota Surabaya memperoleh ajaran atau sosislaisasi dan internalisasi nilai keislaman sejak Taman Kanak-Kanak, Sekolah Dasar (SD), Sekolah menengah bahkan perguruan Tinggi. Dilanjutkan hingga usia dewasa yang tidak berhenti belajar agama, menunjukkan bahwa mereka sejatinya telah mengejawantahkan konsep pendidikan sepanjang hayat (life long education).
Kini interaksi yang dilakukan lebih dilakukan bersama ustadz atau muballigh dalam forum dakwah keagamaan saat memberikan ceramah pada hari besar Islam seperti isra' miraj, maulid nabi Muhammad SAW, kemudian saat hari raya idul fitri maupun hari raya besar idul adha bahkan kegiatan-kegiatan keagamaan yang diadakan jamaah memberikan imunitas secara tranformatif pendidikan informal terhadap pemahaman masyarakat kelas menengah muslim mengenai pengetahuan bahkan ilmu pendidikan yang ia terima di luar sekolah. Dakwah yang dilakukan oleh ustad pada saat memberikan pengajian merupakan tata cara terbaik untuk menyampaikan materi agama guna tersampaikannya amar ma'ruf nahi mungkar.

Pada kegiatan hari besar Islam kebersamaan akan peran masing-masing kelas menengah muslim bisa dilihat dalam bentuk antusias dalam kebersamaan untuk hadir dirangkaian acara yang diselenggarakan pada kegiatan pengajian merupakan bagian dari aktivitas masyarakat kelas menengah ketika ada hari besar Islam, mereka bersama-sama saling bahu-membahu untuk bisa bersilaturrahim. Pada prosesnya sosialisasi mengalami sebuah pengaruh dari dalam maupun individu muslim kelas menengah Surabaya: a) biologis yang meliputi bentuk tubuh (gen), golongan darah, wajah dan alat indera yang memberikan pengaruh, b). Tingkat kecerdasan atau Intelegensi Question (IQ), c). Tingkat emotional atau emotional question (EQ) dan, d). Potensi, bakat serta ketetrampilan, e) Pembentukan kepribadian. 
Syukron Djazilan - Proses Sosialisasi dan Internalisasi Nilai-Nilai Ke-Islaman pada Kelas Menengah Muslim di Surabaya

Dakwah sebagai media yang menjembatani antara masyarakat muslim dengan ustadz untuk mentransformasi nilai-nilai keislaman dikehidupan seharihari mereka sebagai akibat penerimaan yang akan dijalankan. Sosialisasi tidak hanya saat-saat acara kegiatan agama. Hasil analisis peneliti di lapangan yang disajikan dalam paparan data bahwa individu sendiri sangat menentukan proses terjadinya internalisasi untuk menerima nilai-nilai keislaman, kemudian diwujudkan dalam implementasi.

Sosialisasi merupakan sebuah penanaman, transfer kebiasaan dari nilainilai, aturan dari satu generasi kegenerasi, dari masa sebelumnya ke masa selanjutnya dalam sebuah kelompok masyarakat kelas menengah muslim Surabaya yang di lakukan oleh mubaligh/tokoh-tokoh islam baik ulama, kyai, ustd, ustdza dan da'i untuk menyampaikan dan mengajak, menuju terhadap keridhoan tuhan mengenai nilainilai yang diberikan kepda para jamaah untuk menerima, kemudian menjalankan/melaksankan tanpa ada paksaan bagi mereka dalam menjalaninya.

Tujuan utama dari proses sosialisasi nilai-nilai keislaman ialah agar objek/masyarakat mampu memiliki, memahami, menjalankan segala aturan,

\footnotetext{
${ }^{27}$ Lebih Lanjut Lihat Rujukan: Muhammad Faruq Nabhan, Al-Madkhal li al-Tasyri' al-Islam, Dar al-Shadir (Beirut, tt, Jilid VIII), 10, Manna' alQathan, al-Tasyri' wa al-Fiqh al-Islam (Muassasah al-Risalah, tt),14, Muhammad Abu Zahroh, Ushul al-Figh (Dar al-Fikr al-Arabi, 1958), .56. Muhammad Khalid Mas'ud. Filsafat Hukum Islam dan Perubahan Sosial, Penyadur Yudian W. Asmin (Al-Ikhlas Surabaya, 1977),
}

larangan syar'i/aturan, shariah, qanun yang ada baik berdasar aturan pemerintahan maupun utamanya Alquran dan Alhadis serta sunnahnnya. ${ }^{27}$ Ulama, kya, ustad, ustdza, da'i dan mubaligh lainnya merupakan figur central di kalangan masyarakat, kepercayaan terhadap mereka merupakan bisa berdampak terhadap stratifikasi maupun mobilitas sosial dikarenakan memiliki pengaruh terhadap lingkungan keluarga, masyarakat, kampung, kota, hingga lingkungan negara bahkan dunia.

Setiap individu akan mengalami akulturasi(pembudayaan), mengenai agama manakala mereka menerima proses pembelajaran dari sosialisasi dalam mengahayati (internalize) yaitu individu mempelajari, memahami, menyesuaikan, mengenal, alam pikiran sikap, dengan adat, istiadat, sistem norma, peraturan berlaku dalam kebudayaan masyarakat di Surabaya, guna mendukung keberlangsungan hidupnya. ${ }^{28}$ Metode yang di gunakan para ulama/kyai ustd, ustza, da'i merupakan cara terbaik dari sebuah proses sosialisasi nilai-nilai keislaman pada kelas menengah muslim Surabaya, untuk mengajak, menerima ajaran islam melalui kegiatan penagajian, baik dengan kegiatan rutinitas warga nahdhlatu ulama (NU) seperti saat kegiatan yasinan, tahlilan, istighosahan, bahkan pengajian

.125. dan Abi al-Husain Ahmad bin Faris bin Zakariya, Mu'jam Maqayis al-Lughah (Bairut; Dar al-Fikr li al Thaba'ah wal Nasyr, 1979, Juz 1), 486.

${ }^{28}$ Supardi. Dasar-Dasar Ilmu Sosial (Yogyakarta, Ombak, 2011), 83-92, dan M. Munandar Soelaeman. Ilmu Sosial Dasar (Bandung: PT.Grafika Aditama), 166-170. Abuddin Nata. Metodologi Studi Islam (Jakarta: PT Raja Grafindo Persada, 2012), 407-418 
akbar, sholawatan serta acara-acara besar peringatan hari besar islam.

Tata cara/metode yang dilakukan ulama/kyai ustd, ustza, da'i atau mubaligh dengan cara berceramah di atas depan panggung kemudian para jamaah mendengarkan dari apa yang disampaikan hingga beberapa jam kemudian, tidak hanya itu dalam acara tesebut biasa tersugukan hidangan makanan bagi jamaah sehabis acara dengan makan bersama para ulama/kyai ustd, ustza, da'i atau mubaligh, baik makanan, buah-buahan dan jajanan, tidak hanya itu sehabis acara mereka bersalaman, kadang ngobrol satu dengan yang lain menanyakan kabar dan keadaan meskipun satu wilayah desa/kelurahan yang jarang ketemu. Banyak diantara jamaah mengobrol yang langsung didengarkan oleh peneliti, bahwa mereka senang dengan acara-acara kumpul bareng jamaah pengajian, dzikir, istighosahan bahkan sholawatan yang dipimpin tokoh-tokoh masyarakatnya.

Keberadaan kiai dalam lingkungan pesantren merupakan elemen yang cukup esensial laksana jantung bagi kehidupan manusia, Begitu urgen penting adanya kedudukan kiai di lembaga maupun dilingkup masyarakat, karena pemikiran serta dialah yang merintis, mendirikan, mengelola, mengasuh, memimpin dan terkadang pula sebagai pemiliki tunggal dari dua pesantren. Oleh karena itu kiai sangat berperan dalam perubahan serta pertumbuhan suatu lembaga informal yang namanya pesantren sangat tergantung kemampuan pribadi kiainya.

Adapaun faktor dari luar individu yang dapat mempengaruhi yang bisa dijawab ialah: a). Lingkungan keluarga yang sangat mendominasi, b). Lingkungan masyarakat setempat, c). Lingkungan bermain atau bergaul, $d$. Lingkungan pendidikan, e). Lingkungan pekerjaan. Menyampaikan dakwah adalah wajib bagi seluruh umat Islam, seperti perintah dalam al-qur'an proses sosialisasi antara para jamaah dengan ustadz yang dilakukan melalui proses dakwah terus-menerus yang dilaksanakan tanpa ada hentinya yang disebut consolidated yang artinya seseorang atau kelompok orang berasal dari kelompok sosial mempunyai kecendrungan untuk berbaur dengan kelompok yang sama sejak semula mengalamai proses sosialisasi. Perkembangan pendidikan informal semakin bertambah dengan meningkatnya kegiatan-kegiatan keagamaan yang dilakukan masyarakat dan para ustad.

Dengan demikian bisa dikatakan agama mengandung konotasi kebiasaan, adat dan kemampuan yang dimiliki manusia untuk sepenuhnya menyerah pada kudrat dan iradat atau hukum Allah SWT (hukum syariah, hukum alam dan hukum sejarah), pemahaman konseptual seperti ini dapat ditarik melalui pemahaman tentang agama diantaranya adalah bahwa ajaran agama Islamyang terbalut dalam nilai-nilai pendidikan merupakan satu kesatuan yang bisa menjadi tolok ukur kontrol sosial diri kelas menengah dalam membangun dialektika di masyarakat, menurut Islam agama akan melahirkan kultur Islami hal ini dapat dihubungkan dengan konsep Iman Islam, dan Ihsan atau aqidah, ibadah dan akhlak. Makna yang terkandung di dalamnya meliputi atribut, substansi, dan perilaku hingga beribadah yang identik 
Syukron Djazilan - Proses Sosialisasi dan Internalisasi Nilai-Nilai Ke-Islaman pada Kelas Menengah Muslim di Surabaya

dengan takwa yang hakikanya tidak hanya meliputi ibadah mahdhah, tapi juga ibadah muamalah. Inilah yang tercermin melaluinya proses sosialisasi yang berproses dari adanya interaksi yang membentuk akhlak: bersikap, perilaku interaktif dan komunikatif (behavioral) saat mereka melakukan interaksi. Interkasi sosial yang pada akhirnya melahirkan sistem sosial. Sistem Sosial (Social System), yang terdiri atas polapola aktivitas tingkah laku atau tindakan berinteraksi dengan kehidupan masyarakat lingkungan lain. Tindakan ini dapat diobservasi, sehingga sifatnya lebih konkret dalam aktifitas-aktifitas yang ada.

Pembinaan diri selalu ditampilkan dalam bentuk pembinaan berkelanjutan oleh keluarga mulai bayi, kanak-kanak, remaja hingga dewasa. Seperti yang telah diutarakan oleh Murdiono (46), Budiono (39), Sholikin (34) dari kecil hingga dewasa hidup sebagai masyarakat Surabaya. Ia mengatakan bahwa keluarga peletak dasar pondasi pendidikan aqidah, syariat dan akhlak $^{29}$ serta pandangan hidup terhadap pengetahuan agama Islam terhadap thaharah (bersuci), wudhu, bertayamum, bagi perempuan tentang (haid dan nifas dari istihadhah), bimbingan sholat (baik wajib dan sunnah) dan azan maupun iqomah yang ia ketahui. Kemudian pemahaman tentang tempat masjid dan tempat yang dilarang untuk sholat, serta menghadap sholat. Pemahaman-pemahaman seperti ini ia

29 Kebanyakan masyarakat kelas menengah muslim surabaya mempelajari nilai-nilai keislaman/ajaran-ajaran Islam tidak hanya mendengarkan ceramah para kyai, ustadz, ustdza bahkan mereka lebih serius dengan mengkaji kitab-kitab agama berupa kita usul fiqh, fiqh dapat melalui proses sendirinya terhadap nilai-nilai agama yang pernah diperoleh, begitu juga terhadap menunaikan sholat jumat, khotbah jumat, sholat hari raya Idul Fitri, kemudian zakat dan tempat penyaluran zakat. Proses yang berkembang secara mandiri itu tidak terlepas dari personality system. Sistem Personalitas (Personality System), bersangkutan dengan psikologis atau watak pribadi seseorang yang berinteraksi dengan masyarakatnya.

Adapaun nilai-nilai keislaman atau ajaran Islam lainnya ialah kajian terhadap zakat fitrah, shodaqah sunnah, puasa ramadhan dan ulasan kajian terkait puasa. Lailatul qadar, itikaf, adab menjenguk orang sakit, memandikan jenazah dan ulasan mendalamnya dan doa-doa tiap hari yang diajurkan sebagai sebuah pengamalan, kemudian kajian haji dan bahasan nikah beserta ulasannya, bahasan tentang talak, khulu', zhihar, li'an, iddah, hadhanah, hukum (hudud), khamar, hukum zina, had qadzaf, riddah, hirabah, had mencuri, diyat, al-qasamah (sumpah), hukum ta'zir, jihad dan ulasannya, perjanjian, sumpah (aymaan), kafarat (denda) sumpah, nazar, jual beli, riba, qiradh, gadai, muzara'ah, membuka lahan (ihya' maut), ijarah (sewa barang dan kompensasi jasa), pekerja kontrak (ajiir), mudharabah, pengalihan utang (hiwalah), syuf'ah, wakalah, pinjaman (ariyah), titipan (wadi'ah), barang rampasan (ghasab), anak temuan (laqith), barang temuan (luqathah), makanan

sunnah fat-hal-bari maupun kitab-kitab shahih bukhari muslim terkait dasar hadits shahih atau buku yang berkaitan dengan perintah syariat dalam praktek pelaksanaan peribadatan setiap hari, pernyataan diperkuat oleh beberapa sumber dari Murdiono (46), Budiono (39), Sholikin (34). 
ath 'imah, sembelihan yang disyariatkan, perburuan, hewan kurban (al-udhhiyah), aqiqah, kafalah, musaqah, ji'alah, ashshulhu, peradilan, dakwaan dan bukti, ikrar, syahadah (kesaksiaan), sumpah (alyamin), pertentangan, penjara (tahanan), paksaan (al-ikhrah), pakaian, cicilan emas, perak, gambar (at-tashwir), musabaqah (perlombaan), wakaf, hibah, ruqba, nafkah, al-hajru, wasiat, faraid, harta warisan/peneinggalan (tirkah), penerimaan warisan yang berhak. Inilah bahasan yang diberikan saat proses ceramah oleh kyai, ustadz, ustdzah, kemudian pemahaman yang diterimah oleh kelas menengah muslim mengalami perkembangan dari pemahaman ${ }^{30}$.

Proses itulah yang merupakan gambaran internalisasi nilai keislaman pada masyarakat kelas menengah muslim di Surabaya. Secara etimologis, internalisasi menunjukkan suatu proses. Di dalam kaidah bahasa Indonesia kata yang berakhiran-isasi mempunyai definisi sebuah proses. Sehingga internalisasi dapat didefinisikan sebagai suatu proses. Dalam kamus besar bahasa Indonesia internalisasi diartikan sebagai penghayatan, pendalaman, penguasaan secara mendalam yang berlangsung melalui binaan, bimbingan dan sebagainya bagi individu kelas menengah muslim Surabaya dalam menjalankannya. Pola yang berjalan secara melembaga merupakan wujud dari Sistem Organik (Organic System), yang berfungsi sebagai sumber energik dalam keseluruhan sistem organik makhluk atau individu. Proses

30 Ajaran nilai agama yang disampaikan kebanyakan mengkaji nilai-nilai fiqh yang berkembang dimasyarakat dengan berbagai persoalaan yang saat ini menjadi persoalan bagi penanaman nilai keislaman yang terjadi pada Murdiono, Sholikin dan Budiono sejak di bangku sekolah hingga dewasa itulah yang merupakan bentuk pendidikan sepanjang hayat (life long education).

Paling tidak ada empat indikator antara sebagai penguat lain; (1) pendidikan sepanjang hayat menghilangkan tembok pemisah antara sekolah dan lingkungan kehidupan nyata di luar sekolah. Proses sosialisasi dan internalisasi nilai agama sejak tingkat dasar hingga Perguruan Tinggi yang didapatkan di luar sekolah dan PT seperti keluarga dan lingkungan masyarakat, forum dakwah dan teman sejawat.

$$
\text { Kedua. Pendidikan }
$$

sepanjang hayat menempatkan kegiatan belajar sebagai bagian integral dari proses hidup yang berkesinambungan. Hal ini dibuktikan dengan fakta adanya kesinambungan pemerolehan ajaran agama sejak sekolah dasar hingga, PT dan dewasa. Ketiga, pendidikan sepanjang hayat lebih mengutamakan pembekalan sikap dan metode daripada isi pendidikan karena isi pendidikan bersifat statis dan senantiasa berubah. Pembentukan sikap beragama seperti berpakaian, ketaatan beribadah, kepedulian dan kesetiakawanan sosial merupakan fakta yang tidak terbantahkan.

Keempat, pendidikan sepanjang hayat menempatkan peserta didik sebagai individu yang menjadi pelaku utama di dalam proses pendidikan yang mengarah kepada pendidikan diri

umat yang perlu diselesaikan. Seperti penuturan yang disampaikan Murdiono (46), Budiono (39), Sholikin (34). 
Syukron Djazilan - Proses Sosialisasi dan Internalisasi Nilai-Nilai Ke-Islaman pada Kelas Menengah Muslim di Surabaya

sendiri (self education) dan sejalan dengan penciptaan masyarakat gemar belajar (learning society). Hal ini bisa ditemukan dari fenomena belajar agama yang dilakukan kepada usdtadz dalam forum dakwah tanpa aturan formal, membaca referensi dari buku bacaan dan tayangan televisi.

\section{Simpulan dan Saran}

Kajian penelitian ini berupaya untuk mendeskripsikan secara etnografis pola pendidikan Islam informal masyarakat muslim surabaya bahwa pola pendidikan Islam muslim surabaya berproses di dalam kehidupan yang diperankan setiap diri individu dalam wujud hubungan vertikal dan horizontal masyarakat kelas muslim Surabaya antara lain: (1) Proses terjadinya sosialisasi dan internalisasi nilai keislaman berlangsung panjang, dari bangku sekolah hingga dewasa. Pada usia dewasa mereka mendapatkan bimbingan melalui forumforum dakwah oleh ustad/muballigh. Inilah yang disebut dengan belajar sepanjang hayat (life long education).(2) Proses internalisasi dan sosialisasi terkait pelibatan individu yang siap menerima dan mendukung guna menjadikan pendidikan informal semakin meningkatkan taraf kehidupan kelas menengah muslim Surabaya.

Saran yang direkomendasikan pada penelitian ini adalah: (1) Bagi masyarakat kelas menengah muslim Surabaya perlu adanya kerjasama antar lembaga formal, nonformal dalam meningkatkan pendidikan informal di dalam keluarga guna antara pendidikan yang diselenggarakan pemerintah wajib belajar Sembilan tahun bisa terlaksana dan berhasil dan menjadikan kelas menengah muslim Surabaya menjadi lebih baik dan maju. (2) Peran keluarga dalam membentuk manusia ideal berawal dari keluarga, oleh karenanya perlu usaha antar lembaga masyarakat yang mendukung agar pendidikan informal yang dijalankan di dalam keluarga bisa dan mampu berjalan dan mengahdirkan insan paripurna.

\section{DAFTAR PUSTAKA}

Afifuddin,Mohammad, 03 April

2014.Kelas Menengah

Terdesentralisasi, Jawa Pos.

Ahmad,Abi al-Husain bin Faris bin

Zakariya, 1979. Mu'jam

Maqayis al-Lughah. Bairut: Dar

al-Fikr li al Thaba'ah wal

Nasyr, Juz 1.

Al-Qathan,Manna', tt. al-Tasyri' wa al-

Fiqh al-Islam. Muassasah al-

Risalah.

Ardianto,Gunawan, 2010. A To Z Cara

Mendidik Anak Aturan dan

Ajaran Bicara Benar Campur

Tangan Pihak Lain. Jakarta: PT

Elex Media Komputindo.

Bahruddin,Muh, 2012.Mitos Kelas

Menengah ke Atas dalam

Desain Iklan Politik Risma

Bambang. Nirmana, Vol. 14.

Berger,Peter L. dan Thomas Luckman, 1990. Tafsir Sosial Atas

Kenyataan: Risalah Tentang

Sosiologi Pengetahuan. Jakarta: LP3ES.

Berger,Peter L. Langit Suci, 1994. Agama Sebagai Realita Sosial. Jakarta:LPES.

Dokumen File pdf tentang UndangUndang Republik Indonesia Nomor 20 Tahun 2003 Tentang Sistem Pendidikan Nasional.

Hady, Yuswo dan Kemal E Gani, 2015. 8 Wajah Kelas Menengah. Jakarta: Gramedia Pustaka Utama.

Hasan,Noorhaidi, 2016. Islam di KotaKota Menengah Indonesia: Kelas Menengah Gaya Hidup, dan Demokrasi. Jakarta: 
Yayasan Pustaka Obor Indonesia.

http://alkhidmahrobayan..co.id. dikases 24 Oktober 2016.

http://www.bcgsea.com. Diakses pada tanggal 24 Oktober 2016.

http://www.masjidalakbar.com/linkmenu .php? namafile $=$ kajianrutin.diaks es 24 Oktober 2016.

http://www.naqsyabandiyahgersempal.org. dikases 24 Oktober 2016.

Inoue, Yukiko (Ed), 2007. Online education for Lifelong Learning. London: Information Science Publishing.

Jati,Wasisto Raharjo, 2015.Less Cash Society: Menakar Mode Konsumerisme Baru Kelas Menengah Indonesia.Sosioteknologi, Vol. 14.

Khater,Akram Fouad,2001. Inventing Home: Emigration, Gender and The Middle Class In Libanon 1870-1720 Epiloge: The Making of a Middle Class. London: University California Press.

Klinken,Gerry Van dan Ward Berenschot (ed)., 2016. In Search of Middle Indonesia: Kelas Menengah di Kota-Kota Menengah. Jakarta: Yayasan Pustaka Obor Indonesia.

Kuntowijoyo, 2001. Muslim Tanpa Masjid: Esai-Esai Agama, Budaya, dan Politik Dalam Bingkai Strukturalisme Transendental. Bandung: Mizan.
Mas'ud,Muhammad Khalid, 1977. Filsafat Hukum Islam dan Perubahan Sosial. Surabaya: Al-Ikhlas.

Nabhan,Muhammad Faruq, tt. $A l$ Madkhal li al-Tasyri' al-Islam, Dar al-Shadir. Beirut Jilid VIII.

Nata,Abuddin, 2012. Metodologi Studi Islam. Jakarta: PT Raja Grafindo Persada.

Rahardjo,M. Dawam, 1999. Masyarakat Madani: Agama, Kelas Menengah dan Perubahan Sosial. Jakarta: LP3ES dan LSAF.

Richardson,Linda Deer, dkk., 2001. Principles and Practice of Informal Education: Learning Mary Wolfe. London and New York: Routledge Falmer.

Soedijarto, dkk, 2007. Ilmu \& Aplikasi Pendidikan: Bagian 4 Pendidikan Lintas Bidang. Bandung: PT. Imperial Bakti Utama.

Sugiyono, 2007. Metode Penelitian Pendidikan; Pendekatan Kuantitatif, Kualitatif dan $R \& D$. Bandung: Alfabeta.

Supardi, 2011. Dasar-Dasar Ilmu Sosial. Yogyakarta: Ombak.

Tanter,Richard dan Kenneth Young, 1993. Politik Kelas Menengah Indonesia. Jakarta: LP3ES.

Taufik, 2012. Rising Middle Class In Indonesia: Peluang Bagi Marketer dan Implikasi BagiPolicy Maker. Jakarta: Kompas Gramedia.

Zahroh,Muhammad Abu, 1958. Ushul al-Fiqh. Bairut: Dar al-Fikr alArabi. 